\title{
Małgorzata Franczyk
}

Uniwersytet Ekonomiczny w Krakowie

malgorzata.franczyk1@gmail.com

\section{Konsekwencje społeczne i ekonomiczne wydarzeń hybrydowych na przykładzie piątej edycji kongresu Open Eyes Economy Summit}

\section{Streszczenie}

Z uwagi na bardzo szybki rozwój branży spotkań oraz pandemię COVID-19 profesjonaliści zajmujący się organizacją spotkań starają się wdrażać technologię, aby wydarzenia mogły dalej się odbywać w celu wzbogacenia doświadczeń uczestników. Odpowiedzią na powyższe są wydarzenia hybrydowe, które łączą w sobie tradycyjne elementy spotkań z innowacyjnymi technologiami. Celem pracy jest zbadanie konsekwencji ekonomicznych i społecznych wspomnianych wydarzeń z perspektywy organizatora. Metodą badawczą zastosowaną w opracowaniu jest studium przypadku: analiza kongresu Open Eyes Economy Summit oraz wywiad $z$ jego organizatorami. Z badań wynika, że ten sposób organizacji przynosi wiele wymiernych korzyści, przyczynia się do powstawania nowego trendu oraz upatruje się w nim przyszłość branży spotkań.

\section{Wprowadzenie}

Wydarzenia hybrydowe w roku 2020, na skutek pandemii COVID-19, stały się nowym standardem i nową rzeczywistością w branży spotkań. Organizatorzy stanęli przed wyzwaniem przeniesienia wydarzeń stacjonarnych do strefy wirtualnej. Powodem podjęcia tego tematu była chęć usystematyzowania definicji wydarzenia hybrydowego i jego konsekwencji, ponieważ obecna literatura naukowa na ten temat jest niewystarczająca. Celem pracy jest wskazanie konsekwencji ekonomicznych i społecznych wydarzeń hybrydowych z punktu widzenia organizatora piątej edycji Open Eyes Economy Summit. W części pierwszej rozdziału dokonano przeglądu dostępnej literatury zarówno krajowej, jak i międzynarodowej 
z zakresu branży spotkań oraz wydarzeń hybrydowych. W kolejnej części pracy opisano i uzasadniono wybór metody badawczej - studium przypadku - oraz przedstawiono wyniki badań własnych. Opisano kongres Open Eyes Economy Summit i proces organizacji, a także korzyści i bariery formy hybrydowej na podstawie wywiadu przeprowadzonego $z$ organizatorami wspomnianego kongresu. W zakończeniu wyszczególniono najważniejsze wnioski oraz omówiono wyzwania, jakie stoją przed organizatorami.

\section{Przegląd literatury}

Termin branża spotkań jest pojęciem trudnym do jednoznacznego zdefiniowania i sklasyfikowania ze względu na jego stosunkowy młody i złożony charakter (Borodako i in., 2018). W literaturze przedmiotu brakuje systematyzacji pojęciowej, która by w sposób precyzyjny i jednoznaczny wymieniała rodzaje spotkań i wydarzeń mieszczących się $\mathrm{w}$ tym terminie.

Punktem wyjścia jest definicja słowa spotkanie (ang. meeting), które według United Nations World Tourism Organization oznacza: „zgromadzenie w jednym miejscu pewnej liczby osób w celu naradzenia się lub wykonania określonej czynności. Kluczowym celem spotkań jest motywowanie uczestników i prowadzenie działalności biznesowej. Częstotliwość może mieć charakter doraźny lub zgodny $z$ ustalonym schematem, jak np. coroczne walne zgromadzenia, posiedzenia komitetów itp." (Global Meetings Initiative, 2008, s. 2).

Z kolei w „Leksykonie przemysłu spotkań” (Celuch, 2015) spotkanie określane jest jako wydarzenie, podczas którego podstawową aktywnością uczestników jest udział w sesjach edukacyjnych i biznesowych, a także w wydarzeniach towarzyszących powiązanych $z$ danym tematem.

Zamiennie używa się terminu przemysł spotkań, który definiowany jest jako „całość zjawisk i procesów związanych z organizacją spotkań na danym terenie w określonym czasie. Zastosowanie terminu przemysł spotkań podkreśla gospodarcze (i w konsekwencji społeczne) znaczenie przeprowadzania spotkań dla danego obszaru - miasta, regionu, kraju" (Borodako i in., 2014, s. 63).

Szeroko rozumiany rynek przemysłu spotkań tworzą dwie strony: podmioty reprezentujące stronę popytową oraz podażową. Osoby zgłaszające popyt na usługi organizacji wydarzeń to najczęściej korporacje, organizacje rządowe i pozarządowe. Stronę podażową natomiast reprezentują pośrednicy oraz dostawcy usług cząstkowych, np. obiekty spotkań, obiekty noclegowe czy firmy transportowe (Cieślikowski, 2015).

Pośrednicy mogą reprezentować stronę popytową, w imieniu nabywców, a także stronę podażową, w imieniu dostawców. Do pierwszej kategorii zaliczyć można profesjonalnego organizatora konferencji i kongresów (Professional Conference Organiser, w skrócie PCO). Davidson i Cope (2003) definiują PCO jako menedżera produktu, w tym wypadku całej imprezy, oraz konsultanta doradzającego często w takich kwestiach, jak: techniki komunikacji, marketing czy public relations. W imieniu nabywców działają również venue finder agencies, czyli agencje 
zajmujące się wyszukiwaniem odpowiednich miejsc do organizacji wydarzenia. Po stronie pośredników pracujących w imieniu dostawców wyróżnia się convention bureau - biura spotkań, które są organizacjami non profit, reprezentującymi dane państwo, miasto lub region oraz firmy zajmujące się określoną destynacją (destination management companies, w skrócie DMC).

Z uwagi na dynamiczny rozwój branży spotkań, coraz częściej w celu zwiększenia konkurencyjności na rynku wprowadza się szereg innowacji do procesu organizacji i realizacji wydarzenia. Przykładem może być wydarzenie hybrydowe, które identyfikowane jest jako najnowszy gatunek planowanych spotkań o kluczowym znaczeniu dla rozwoju branży. Dostępna literatura naukowa dotycząca spotkań wirtualnych jest niewystarczająca, odnotowano bardzo niewiele badań akademickich w tym zakresie. Sam termin wydarzenia hybrydowe w polskiej literaturze naukowej jest nowy, jego definicja tworzy się teraz, w czasie rzeczywistym, którym jest okres światowej pandemii.

W oparciu o przytoczone definicje branżowe wirtualne spotkanie jest „spotkaniem na żywo z wykorzystaniem wirtualnej platformy dostarczanej przez korporację platformy wirtualnej (eventowej) (lub takiej, która została zbudowana na zamówienie klienta), lub prezentowanej w wirtualnym świecie" (Sox i in., 2017). Technologia ta wykorzystywana jest przede wszystkim do sprawniejszej komunikacji z uczestnikami spotkania.

Wydarzenie hybrydowe jest zatem spotkaniem, które „obejmuje połączenie zdarzeń fizycznych i cech spotkania wirtualnego, zazwyczaj odbywającego się jednocześnie, z nakładającymi się na siebie informacjami i komponentami interaktywnymi" (Virtual Edge Community, 2009). W modelu hybrydowym możliwość jednoczesnego zaangażowania mają osoby przebywające fizycznie w obiekcie, a także wirtualni uczestnicy.

Sox i in. (2014) przytaczają definicję, w której wydarzenia hybrydowe to wydarzenia cyfrowe, spotkania i technologie edukacyjne, które obejmują: media strumieniowe, rzeczywistość wirtualną (2D i 3D). Transmisja strumieniowa daje dostęp do zasobów takich, jak pliki audio i wideo: „treści multimedialne są jednocześnie pozyskiwane i transmitowane w czasie bliskim czasu rzeczywistego. Dane multimedialne docierają do wszystkich użytkowników z dowolnego, odległego od nich miejsca na świecie. Ponieważ zdarzenia utrwalone za pomocą danych multimedialnych są przekazywane do użytkownika na bieżąco, użytkownik nie ma możliwości sterowania transmisją" (Sulej, Ziółkowska, 2011). Platforma musi być zabezpieczona, aby tylko zarejestrowani uczestnicy mogli dołączyć do spotkania. Zapewniona musi być również pomoc i obsługa uczestników w przypadku problemów z podłączeniem się do wydarzenia.

Wydarzenia są nagrywane jako pliki multimedialne i ponownie strumieniowane w różnych formatach, co oznacza, że różni odbiorcy mobilni mogą odbierać transmisję strumieniową i brać udział w wydarzeniu zdalnie. Sposób ten ułatwia dotarcie do większej liczby odbiorców na całym świecie. Transmisja jest zazwyczaj nagrywana, dzięki czemu materiały mogą być udostępnione uczestnikom po zakończeniu wydarzenia, co daje możliwość powrotu do prezentacji (Hoods, Pakarinen, 2018). 
Jednakże, aby wydarzenie wirtualne zaklasyfikowane zostało jako wydarzenie w ramach branży spotkań, musi zaistnieć interakcja z uczestnikami. Kluczowe jest zapewnienie strefy networkingu, gdzie spotykają się dwa komponenty - świata realnego i wirtualnego, czyli tradycyjne elementy spotkania $z$ innowacyjną technologią. Wirtualna rzeczywistość jest nieograniczona, wykorzystywane platformy pozwalają na łączenie $\mathrm{w}$ pokoje wirtualne, wykonywanie wspólnych zadań, dyskutowanie, rozmawianie z partnerami i sponsorami wydarzenia. Dzięki temu w trakcie sesji uczestnicy są praktycznie obecni i mogą współdziałać tak, jak w przypadku tradycyjnego wydarzenia. Bycie faktycznie obecnym pozwala na utrzymanie zainteresowania. Wiedza, tematy i prezenterzy są jednym z powodów, dla których uczestnicy biorą udział w wydarzeniach. Drugim jest właśnie kontakt z ludźmi, budowanie kontaktów społecznych i biznesowych (Hoods, Pakarinen, 2018).

\section{Metodyka badań}

W niniejszej pracy wybrano metodę jakościową - studium przypadku (ang. case study), ponieważ cechuje się ona holistycznym podejściem. Nie polega tylko na zbieraniu danych, dokumentowaniu ich i przeszukiwaniu materiałów, ale także na głębokiej analizie i zrozumieniu pojedynczego przypadku. „Charakteryzuje się rygorystycznymi wymogami, ale dopuszcza znaczną elastyczność, zwłaszcza gdy chodzi o nietypowy problem badawczy" (Wójcik, 2013, s. 18). Według Yina (2003) ta metoda badania składa się z trzech głównych etapów: (1) definiowania i projektowania badania, (2) przygotowania do zbierania danych, (3) zbierania danych i ich analizy oraz wnioskowania.

Za pomocą tej metody można znaleźć odpowiedzi na pytania, ,jak” i „dlaczego" omawiane zjawisko występuje. Dodatkowo stwarza ona możliwość wyjaśnienia związków przyczynowo-skutkowych, których nie da się zweryfikować i ocenić za pomocą ankiety. Case study jest szczególnie przydatne do badań ewaluacyjnych, które pozwalają dokonać oceny badanych zjawisk (Lisiecka, Kostka-Bochenek, 2009). „Każda $z$ technik badawczych może być zastosowana przy metodzie indywidualnych przypadków, jeżeli przyniesie pożądane skutki. Wysoce użyteczny pod względem badawczym jest wywiad, badania środowiskowe, a także badania dokumentów" (Apanowicz, 2002, s. 70). Powodem użycia tej metody była wyjątkowość opisywanego zjawiska.

Pierwszym etapem procesu badawczego była analiza wydarzenia Open Eyes Economy Summit na podstawie informacji dostępnych na stronie internetowej wydarzenia oraz publikowanych postów w social mediach. Drugim etapem było przeprowadzenie wywiadu z organizatorami tegoż kongresu. Celem badawczym była analiza wydarzenia hybrydowego oraz wskazanie skutków ekonomicznych i społecznych, jakie niesie ze sobą ten model organizacji z punktu widzenia organizatora OEES. Wywiad składał się z jedenastu pytań otwartych merytorycznych oraz dwóch pytań metryczkowych. 


\section{Wyniki badań}

Wywiad udało się przeprowadzić zdalnie na początku stycznia 2021 r. z dyrektorem zarządzającym Open Eyes Economy Summit - Kingą Taćkiewicz, która koordynuje prace organizacyjne i produkcyjne całego zespołu, zarządza budżetem i harmonogramem oraz prowadzi ewaluację projektu.

Międzynarodowy Kongres Ekonomii Wartości Open Eyes Economy Summit (w skrócie OEES) to doroczny szczyt ekonomiczny odbywający się w Krakowie od 2016 r. Jego celem jest szerzenie i realizacja nowych, otwartych spojrzeń na ekonomię, a także inspirowanie do działania i wymyślania alternatywnych sposobów rozumienia gospodarki opartej na wartościach. Prowadzone są debaty, seminaria i konferencje, łączące ludzi z rozmaitych branż i środowisk, poruszające różnorodne tematy oraz tworzące niestandardowe i nieoczekiwane połączenia. Udział w kongresie biorą politycy, aktywiści, naukowcy, studenci, dziennikarze i artyści. Jak mówią o sobie sami organizatorzy - OEES to „tygiel nowych idei, fuzja rozmaitych horyzontów i prawdziwa współczesna agora" (https://oees.pl; dostęp: 2.01.2021). Piąta edycja Open Eyes Economy Summit odbyła się 17-18 listopada $2020 \mathrm{r}$. i przyjęła formę hybrydową.

Pierwsze cztery edycje OEES (2016-2019) każdego roku gromadziły w Centrum Kongresowym ICE prawie 3 tys. uczestników i 200 prelegentów z całego świata. Organizując poprzednie edycje, nie korzystano z narzędzi zdalnego łączenia się - uczestnicy i prelegenci spotykali się w Krakowie, gdzie w ciągu dwóch dni na żywo dyskutowali o ekonomii przyszłości. Nie oznacza to jednak, że organizatorzy OEES nie mieli doświadczenia w wirtualnych wydarzeniach. Jak mówi Kinga Taćkiewicz: „po ogłoszeniu obostrzeń w związku z pandemią COVID-19 ruszyliśmy z szeregiem projektów i mniejszych wydarzeń online, których w pierwszej połowie roku 2020 zorganizowaliśmy ponad 30. To doświadczenie doskonale przygotowało zespół do organizacji w formule hybrydowej tak dużego przedsięwzięcia jak OEES".

Razem $z$ wprowadzeniem technologii do branży spotkań, tradycyjne zarządzanie wydarzeniami znacznie się zmieniło - obecnie panuje czas wydarzeń wirtualnych. Podczas rozmowy zapytano o korzyści wynikające $z$ hybrydowego modelu organizacji eventu z punktu widzenia właściciela wydarzenia oraz wszystkich pozostałych firm tworzących zespół organizatora. Dyrektor zarządzający jako największą korzyść wskazała zwiększenie dostępności kongresu dla odbiorców - zarówno uczestników, jak i prelegentów. Brak konieczności podróży do Krakowa daje szansę na dotarcie do dotychczas nieosiągalnych prelegentów. Jako potwierdzenie można wskazać wystąpienie w piątej edycji OEES laureata Pokojowej Nagrody Nobla - Muhammada Yunusa. Omawiana edycja OEES „odbyła się pod hasłem \#wszedziegdziechcesz, dzięki temu promowaliśmy możliwość uczestniczenia w Kongresie $z$ każdego miejsca na świecie: $z$ biura, z plaży, z łóżka, w podróży - wszędzie. Technologia, jaką przygotowaliśmy na OEES, dawała takie rozwiązania”. Kolejne wymierne korzyści można wskazać dla firm zajmujących się produkcją i realizacją wydarzeń, które szybko odnalazły się w nowej 
rzeczywistości i zaczęły budować platformy do streamingu, oferować usługi zdalnej organizacji wydarzeń z całą obsługą technologiczną.

Korzyści pojawiają się również w kwestii ekonomicznej. Koszty wzięcia udziału dla uczestników piątej edycji kongresu zostały obniżone o $25 \%$ w porównaniu z poprzednią edycją. Czyni to wydarzenie jeszcze bardziej dostępnym dla większego grona potencjalnych zainteresowanych. Jeśli chodzi o całkowity budżet, można stwierdzić, że koszt organizacji wydarzenia online jest niższy, w przypad$\mathrm{ku}$ OEES o $15 \%$.

Niestety pozostałe gałęzie branży spotkań (hotele, gastronomia, transport) ponoszą duże straty ze względu na brak spotkań na żywo. Brak uczestników czy mniejsza liczba uczestników na miejscu automatycznie oznacza zmniejszenie zapotrzebowania na te usługi. Jak zauważa Kinga Taćkiewicz: „wydarzenie w zdalnej formule niestety znacząco skraca łańcuch dostawców". Zapytano więc, jakie działania i rozwiązania wykorzystano przy organizacji OEES, aby zachować łańcuch podwykonawców i które z tych działań były innowacyjne. W kwestii produkcji i realizacji wizji, obsługi multimediów i systemu rejestracyjnego organizatorzy skorzystali $z$ usług tych samych firm, co przy poprzednich edycjach. Zmieniło się zamówienie na catering, było 10 razy mniejsze, współpraca z hotelami również była symboliczna. „Zdecydowaną innowacją był fakt, że zdecydowaliśmy się wysłać welcome-packi do domów naszych zarejestrowanych uczestników, co zrealizowaliśmy przy nieocenionej pomocy zaprzyjaźnionej firmy kurierskiej oraz wsparciu naszych partnerów, którzy wypełnili przesyłkę gadżetami i publikacjami".

Wirtualna frekwencja to zupełnie nowy sposób uczestniczenia w wydarzeniach, który wpływa na proces uczenia się, zdobywania wiedzy oraz doświadczenia uczestników i prelegentów w sferze networkingu. Rozmówca wskazuje, że „organizując OEES $5 \mathrm{w}$ formule hybrydowej, musieliśmy kompletnie przeprogramować swoje myślenie o Kongresie, a cały know-how zdobyty przy poprzednich edycjach okazał się niewystarczający. Musieliśmy zdynamizować program, zaplanować go tak, aby uczestnik nigdy się nie znudził, aby każdy kolejny punkt, każda aktywność na platformie była bardziej angażująca niż poprzednia”. Zbudowana, na potrzeby piątej edycji OEES, platforma dawała możliwość „networkingu przy 5 stolikach tematycznych, czytania publikacji przygotowanych specjalnie na kongres, odwiedzania wirtualnych stanowisk partnerów, a nawet łączenia się z nimi, zadawania pytań prelegentom $\mathrm{w}$ indywidualnych sesjach Q\&A, a do tego przez dwa dni nadawaliśmy program OEES równolegle $z$ czterech scen, a w przerwach działało studio live, które pokazywało to, co działo się w Centrum Kongresowym ICE". Z ankiet, które organizatorzy przeprowadzili wśród uczestników, wynika, że w kwestii zdobywania wiedzy uczestnicy zyskali więcej w porównaniu z wydarzeniem stacjonarnym. Z łatwością można było przemieszczać się między scenami, wystąpieniami, odtwarzać nagrania, prowadzić dyskusje na czacie i komentować panele.

W realizacji wydarzenia hybrydowego niezbędne jest wykorzystanie innowacji technologicznych. Organizatorzy OEES 5 są zadowoleni z narzędzi, z jakich skorzystali podczas całego procesu organizacji. „Za innowacyjną uważamy przede 
wszystkim zbudowaną przez nas platformę OEES 5 - to przełomowe pod kątem funkcjonalności rozwiązanie w branży, które umożliwiło uczestnikom dostęp do:

1. 4 scen live i studia OEES.

2. 5 networkingowych stolików tematycznych wraz z Q\&A z wybranymi mówcami.

3. 19 stanowisk $\mathrm{w}$ strefie expo, w tym 16 spotkań live z przedstawicielami partnerów.

4. Aktualnej agendy z możliwością dodania poszczególnych punktów do swojego kalendarza.

5. Profili speakerów.

6. Publikacji OEES i materiałów kongresowych do pobrania.

7. Sklepu internetowego z możliwością zakupu publikacji prelegentów (BOOKSHOP).

8. Live chatów wraz z możliwością prywatnych czatów pomiędzy użytkownikami”. Kongres OEES 5 stał się największym wydarzeniem zdalnym w kraju. Wzięło w nim udział 3000 osób, w tym 160 prelegentów, z 27 krajów. W przyszłości planuje się nadal wykorzystywać streaming i możliwość zdalnego łączenia mówców, a także rozszerzenie hybrydy do obecności publiczności w liczbie około 100 osób. To pozwoli zwiększyć frekwencję, a co najważniejsze, dać wybór uczestnikom: „dla osób, dla których najważniejszy jest networking, będzie możliwość udziału stacjonarnie, a ci, którzy bardziej dbają o merytorykę i zwiększenie wiedzy, obejrzą Kongres z dowolnego, wybranego przez siebie miejsca”. Ta wypowiedź wskazuje na tworzenie się trendu dotyczącego różnicowania uczestników ze względu na ich potrzeby i cele - uczestnicy online, którzy jako główny motyw udziału w wydarzeniu wirtualnym widzą aspekt merytoryczny i zdobywanie wiedzy, oraz uczestnicy stacjonarni, dla których ważniejsze są relacje i kontakty z innymi ludźmi.

\section{Podsumowanie}

Badania wskazują wiele korzyści, ale również barier i negatywnych skutków hybrydowego modelu organizacji wydarzenia. Organizatorom rzeczywistość wirtualna pomaga obniżyć koszty i zwiększyć zyski, ponieważ liczba uczestników jest dowolna, a samo wydarzenie nie jest ograniczone żadnymi elementami fizycznymi. Oszczędności wynikają z braku konieczności rezerwacji obiektów noclegowych, biletów lotniczych i kolejowych dla mówców, mniejszej potrzeby korzystania z usług cateringowych oraz firm transportowych. Swoje zyski zdecydowanie zwiększają firmy zajmujące się produkcją i realizacją wydarzeń poprzez stworzone platormy do streamingu oraz oferty zdalnej organizacji wydarzenia.

Brak konieczności podróży do danego miejsca i możliwość wirtualnego łączenia się zwiększa dostępność wydarzenia dla uczestników i przyczynia się do poszerzenia potencjalnych kręgów osób zainteresowanych danym produktem, w tym wypadku kongresem OEES. Stworzona platforma i szereg wprowadzonych innowacji pozwala również budować przewagę konkurencyjną na rynku. 
Konsekwencje społeczne zauważa się też w strukturze zatrudnienia. Wydarzenia wirtualne znacząco skracają łańcuch podwykonawców w porównaniu z wydarzeniem stacjonarnym. Przekłada się to realnie na zmniejszenie wielkości zatrudnienia w pozostałych gałęziach branży spotkań, takich jak gastronomia, transport czy zakwaterowanie.

Dla organizatorów wydarzeń hybrydowych kluczem do sukcesu jest zaangażowanie wszystkich uczestników i sprawienie, by czuli się oni częścią danego wydarzenia, a także umiejętność odpowiedzi na powstający nowy trend wśród uczestników, czyli zapewnienie możliwości uczestnictwa stacjonarnego osobom, dla których ważny jest networking, ale również uczestnictwa zdalnego osobom, dla których priorytetem jest aspekt merytoryczny. Analizowany model organizacji wydarzeń daje ogrom możliwości i wymiernych korzyści. Nie bez powodu zatem w formie hybrydowej upatruje się przyszłość branży spotkań.

\section{Literatura}

Apanowicz J. (2002). Metodologia ogólna. Wydawnictwo Diecezji Pelplińskiej Bernardinum, Gdynia.

Borodako K., Berbeka J., Niemczyk A., Seweryn R. (2014). Wpływ ekonomiczny przemysłu spotkań na gospodarkę Krakowa. Fundacja Uniwersytetu Ekonomicznego w Krakowie, Kraków.

Borodako K., Berbeka J., Niemczyk A., Seweryn R. (2018). Wpływ ekonomiczny branży spotkań na gospodarkę Krakowa. Małopolska Organizacja Turystyczna, Kraków.

Celuch K. (2015). Leksykon przemysłu spotkań. Turystyka biznesowa, event marketing, podróże motywacyjne. Biblioteka Meeting Plannera, Warszawa.

Cieślikowski K. (2015). Zarządzanie turystyką biznesową. Wybrane aspekty globalne i lokalne. Wydawnictwo Akademii Wychowania Fizycznego w Katowicach, Katowice.

Davidson R., Cope B. (2003). Turystyka biznesowa. Konferencje, podróże motywacyjne, wystawy, turystyka korporacyjna. Polska Organizacja Turystyczna, Warszawa.

Global Meetings Initiative (2008). Identifying the link between tourism and the Meeting Industry: case studies. Vol. 1. UNWTO Department of Statistics and Tourism Satellite Account, Madrid.

Hoods J., Pakarinen T. (2018). From hybrid events to the next generation - interactive virtual events. Viewed from three different stakeholders' point of view. Lahti University of Applied Sciences, Lahti.

Lisiecka K., Kostka-Bochenek A. (2009). Case study research jako metoda badań naukowych. Przegląd Organizacji, 10(837).

Open Eyes Economy Summit (https://oees.pl; dostęp: 2.01.2021).

Sox C., Crews T., Kline S. (2014). Virtual and Hybrid Meetings for Generation X: Using the Delphi Method to Determine Best Practices, Opportunities, and Barriers. Journal of Convention \& Event Tourism, 15: 150-169.

Sox C., Kline S., Crews T. (2017). Virtual and Hybrid Meetings: Gaining Generational Insight From Industry Experts. International Journal of Hospitality \& Tourism Administration, 18, 2: 133-170.

Sulej W., Ziółkowska M. (2011). Efektywność mediów strumieniowych. Biuletyn Instytutu Automatyki i Robotyki, 30. 
Wójcik P. (2013). Znaczenie studium przypadku jako metody badawczej w naukach o zarządzaniu. E-mentor, 1(48): 17-22.

Virtual Edge Community (2009). Virtual Event Definitions (www.virtualedge.org/page/ virtual-event-definitions; dostęp: 21.12.2020).

Yin R. (2003). Case study research: design and methods. Thousand Oaks, London-New Delhi.

\section{Social and economic consequences of hybrid events in the 5th Edition of the Open Eyes Economy Summit}

Due to the very rapid development of the meeting industry and the COVID-19 pandemic, meeting professionals are trying to implement technology so that events can continue in order to enrich the experience of participants. The answer to this is hybrid events, which combine traditional meeting elements with innovative technologies. The purpose of this work is to examine the economic and social consequences of these events from the perspective of the event organiser. The research method used in the study is a case study - an analysis of the Open Eyes Economy Summit Congress and an interview with its organizers. Research has shown that this way of organizing brings many tangible benefits, contributes to a new trend and sees the future of the meeting industry. 